\title{
The relationship of city and small business economic parameters
}

\author{
Andrey N. Vazhdaev \\ Information Systems Department, Yurga Institute of \\ Technology National research TPU Affiliate \\ Yurga, Russia \\ vazhdaev@tpu.ru \\ Artur A. Mitsel \\ Information Systems Department, Yurga Institute of \\ Technology National research TPU Affiliate \\ Yurga, Russia \\ Tomsk State University of Control Systems and \\ Radioelectronics \\ Tomsk, Russia \\ maa@asu.tusur.ru
}

\author{
Marina V. Grigoryeva \\ Information Systems Department, Yurga Institute of \\ Technology National research TPU Affiliate \\ Yurga, Russia \\ Tomsk State University of Control Systems and \\ Radioelectronics \\ Tomsk, Russia \\ marina241063@mail.ru
}

\begin{abstract}
The article presents the results of a study on dependencies between the macroeconomic parameters of Yurga City and those of financial-economic activity in small businesses.
\end{abstract}

Keywords - aggregated economic parameters; small enterprises; correlation; municipalities; micro-parameters.

\section{INTRODUCTION}

Small business enterprises are newly created or operating enterprises with a certain quantitative criterion of the number of employees and the volume of economic turnover $[1,2,3]$. They include businesses with a maximum number of industry and construction employees up to 200 people, those of science and scientific services - up to 100 , of other manufacturing sector branches - up to 25 , of retail trade - up to 15 (the decree "On measures to create and develop Small Enterprises" of August 8, 1990).

Previous studies [1] have shown that new activities for small businesses can appear throughout the life of the enterprise. From the very beginning of its existence, any enterprise makes effort to develop and become more stable in an aggressive business environment. One of the tools to stabilize and achieve sustainable growth is activity diversification, i.e. the creation and opening of new business lines. The main reasons for the small business enterprise to create new business lines are as follows $[1,3,4,5,6]$ :

1. The specifics and nature of running a small business are built on the constant search for effective means to generate profit and achieve set goals.

2. A successful primary small business venture provides financial and other type resources that enable organization of new business lines within the existing small business enterprise.

3 . In the process of following the primary business line, additional measures may be required to support and develop it. These measures may in time "turn" into a new business line or lines.

4. High (tax, accounting, political, competitive, etc.) risks force small business owners to diversify their activities by opening new lines of business.

5. Optimization of tax accounting in terms of the legislation is an existing opportunity to reduce tax burden on the small enterprise with the use of various accounting mechanisms in different business lines, for example, by joint use of special taxation regimes: simplified taxation system (STS) and unified tax on imputed income (UTII).

6. New directions of activity may cause the synergy effect - an additional leap in the development of both existing small enterprise business lines, and the small business enterprise itself $[4,5,6]$.

Thus, the emergence of new lines in the economic activity for small enterprises is a natural process in their functioning [1,3-8].

The subject of this paper is the study of the dependencies between the dynamics of macroeconomic parameters of the city of Yurga and the parameters of financial and economic activity of small enterprises.

\section{YURGA ECONOMIC PARAMETERS DATA ORIGINATION}

Two main sources on the 2007-2015 period were taken as a resource for the economic parameter data of the mono-city of Yurga: annual reports of the Yurga mayor on the social and economic city development from the official city website [9] and the website part of the Russian Federal State Statistics Service (FSSS) [10] that contains parameters characterizing the state of the economy and social sphere of this municipal formation.

The above sources contain a large amount of data. Thus, the FSSS database contains about 2.5 thousand 
economic and social parameters for the city of Yurga; whereas reports the Yurga mayor contain 11 main sections with more than 300 different parameters. Therefore, to conduct research it was necessary to take only those parameters that have the greatest direct impact on the development of small businesses in the mono-city and / or reflect the city economic and social development at most.

Following the analysis, only the succeeding parameters were left to study the relations with small businesses (Table. 1).

TABLE I. THE MAIN ECONOMIC PARAMETERS OF YURGA IN 2007-2015

\begin{tabular}{|l|c|c|c|}
\hline Parameter & $\mathbf{3 1 . 1 2 . 2 0 0 7}$ & $\mathbf{3 1 . 1 2 . 2 0 1 0}$ & $\mathbf{3 1 . 1 2 . 2 0 1 3}$ \\
& $\mathbf{3 1 . 1 2 . 2 0 0 8}$ & $\mathbf{3 1 . 1 2 . 2 0 1 1}$ & $\mathbf{3 1 . 1 2 . 2 0 1 4}$ \\
& $\mathbf{3 1 . 1 2 . 2 0 0 9}$ & $\mathbf{3 1 . 1 2 . 2 0 1 2}$ & $\mathbf{3 1 . 1 2 . 2 0 1 5}$ \\
\hline 1. UTII for certain & 31718.00 & 40624.10 & 49546.90 \\
types of activities, & 31522.00 & 45716.00 & 55145.70 \\
thousand rubles & 33979.40 & 50980.80 & 52156.50 \\
\hline 2. Number of self- & 2100.00 & 2268.00 & 1750.00 \\
employed & 2000.00 & 2183.00 & 1723.00 \\
entrepreneurs & 2602.00 & 2183.00 & 1670.00 \\
\hline 3. Number of small & 400 & 483 & 697 \\
businesses & 393 & 483 & 702 \\
& 364 & 633 & 750 \\
\hline 4. Personal income & 226628.00 & 273005.10 & 402920.90 \\
tax, thousand rubles & 271449.00 & 332451.30 & 353865.60 \\
& 265780.40 & 414938.50 & 362935.60 \\
\hline 5. Taxes on total & 31724.00 & 40655.10 & 49899.80 \\
income, thousand & 31525.00 & 45886.70 & 55552.70 \\
rubles & 33988.10 & 51227.20 & 53156.50 \\
\hline 6. Average monthly & 9445.00 & 13638.00 & 16720.30 \\
nominal income per & 12547.00 & 14904.60 & 19422.00 \\
capita, rubles & 11722.40 & 15978.20 & 20539.20 \\
\hline 7. Population, & 83836.00 & 81454.00 & 81446.00 \\
people. & 83883.00 & 81180.00 & 81139.00 \\
& 83860.00 & 81385.00 & 81396.00 \\
\hline 8. The number of & 25 & 21 & 20 \\
large and medium- & 25 & 21 & 20 \\
sized enterprises & 23 & 20 & 16 \\
\hline
\end{tabular}

\section{ORIGINATION AND COLLECTION OF DATA ON ECONOMIC PARAMETERS OF SMALL ENTERPRISES IN YURGA}

An official list of subjects of Yurga mono-city small and medium-sized businesses was found. The Federal website of the unified state register for small and medium-sized businesses allows collecting such data. Only legal entities were selected from the register of small and medium-sized business subjects.

Table. 2 presents data on the number of small enterprises in corresponding periods whose financial parameters were collected for analysis.

The initial data sets for the analysis of economic parameters were the balance sheet and profit and loss accounting forms.

To make the obtained data less dependent on the number of small enterprises for each sample year, it was decided to take the "Revenue" parameter as the basic one.
The weight of each of the small business enterprise was found in the total revenue for each year and the obtained weight value was multiplied by the value of the parameters under study for each enterprise. After that, the obtained values for each of the parameters were added to the final values by years.

TABLE II. THE NUMBER OF SMALL ENTERPRISES UNDER STUDY BY YEARS

\begin{tabular}{|c|c|c|}
\hline $\begin{array}{c}\text { Period } \\
\text { number }\end{array}$ & Year & $\begin{array}{c}\text { Number of small enterprises with } \\
\text { parameters taken for study sample }\end{array}$ \\
\hline 1 & 2007 & 41 \\
\hline 2 & 2008 & 43 \\
\hline 3 & 2009 & 41 \\
\hline 4 & 2010 & 54 \\
\hline 5 & 2011 & 58 \\
\hline 6 & 2012 & 104 \\
\hline 7 & 2013 & 252 \\
\hline 8 & 2014 & 291 \\
\hline 9 & 2015 & 320 \\
\hline
\end{tabular}

In addition, since the number of enterprises studied was different for different years, it became necessary to bring data for different years to a relative form. It was thus decided to determine the relationship of all total aggregate balance-of-payments parameters to the corresponding value of the "Balance" parameter. Thus, the analyzed aggregate parameters were transformed into the following:

1. Revenue was determined as the average value the ratio of the total annual revenue value to the number of small businesses under study for the corresponding year.

2. The ratio of the "Total for Section I (Non-current Assets)" parameter to the "Balance" parameter: NCAB.

3. The ratio of "Total for Section II (Current assets)" to the "Balance": CAB.

4. The ratio of "Total for Section III (Capital and Reserves)" to the "Balance": CRB.

5. The ratio of the "Total for Section IV (Long-term liabilities)" to the "Balance": LTLB.

6. Ratio of "Total for section V (Short-term liabilities)" to the "Balance": STLB.

7. The ratio of the "Aggregate financial result of the period" to the "Revenues ": ARR.

Table. 3 shows the values of parameters for the period of research, but already with the weight coefficients to the basic parameter. 
TABLE III. AGGREGATED VALUES OF PARAMETERS WITH CONSIDERATION OF WEIGHTS BY YEARS

\begin{tabular}{|l|c|c|c|c|c|c|}
\hline Year & Revenues & NCAB & CAB & CRB & LTLB & STLB \\
\hline 2007 & 18286 & 0.250 & 0.727 & 0.496 & 0.037 & 0.446 \\
\hline 2008 & 19403 & 0.217 & 0.752 & 0.542 & 0.033 & 0.395 \\
\hline 2009 & 24648 & 0.213 & 0.779 & 0.559 & 0.020 & 0.422 \\
\hline 2010 & 23594 & 0.237 & 0.744 & 0.482 & 0.028 & 0.488 \\
\hline 2011 & 23133 & 0.230 & 0.768 & 0.360 & 0.039 & 0.539 \\
\hline 2012 & 19817 & 0.232 & 0.741 & 0.457 & 0.064 & 0.472 \\
\hline 2013 & 13024 & 0.217 & 0.768 & 0.449 & 0.043 & 0.506 \\
\hline 2014 & 11865 & 0.187 & 0.786 & 0.446 & 0.034 & 0.507 \\
\hline 2015 & 11392 & 0.190 & 0.791 & 0.387 & 0.033 & 0.556 \\
\hline
\end{tabular}

IV. INVESTIGATION OF DEPENDENCIES BETWEEN YURGA CITY MACRO-PARAMETERS AND SMALL ENTERPRISE ECONOMIC PARAMETERS

To investigate the dependencies between the economic parameters of Yurga and the economic performance of small enterprises, the correlation coefficient between the pairs of variables was used: each of the microeconomic parameters under study and one of the economic macro-parameters. All calculations were carried out in the information system previously developed by one of the authors [1] and in the MS Excel software program. For the calculated correlation coefficients, an evaluation of the significance was made based on the Student t-criterion:

$$
t_{p a c}=\frac{|r|}{\sqrt{1-r^{2}}} \sqrt{n-2},
$$

where $r$ - correlation coefficient, $n$ - sample size. Correlation is considered significant with $t_{p a c}>t_{q}(n-2)$. Here, $t_{q}(n-2)$ is the critical value of Student's statistics at the significance level $q$. For $q=0.05$ and $n=9$ the value is $t_{q}(n-2)=2.36[11]$.

Table. 4 presents the results of calculating the correlation coefficients between the aggregated economic parameters of small businesses and the city macro-parameters. Significant correlation coefficients for the Student's criterion are highlighted against a dark background.
TABLE IV. CORRELATION COEFFICIENTS BETWEEN CITY ECONOMIC PARAMETERS AND AGGREGATED MICRO-PARAMETERS

\begin{tabular}{|c|c|c|c|}
\hline \multirow{2}{*}{$\begin{array}{l}\text { Parameters of the } \\
\text { city }\end{array}$} & \multicolumn{3}{|c|}{ Micro-parameters } \\
\hline & $\begin{array}{l}\text { Revenues } \\
\text { NCAB }\end{array}$ & $\begin{array}{l}\text { CAB } \\
\text { CRB }\end{array}$ & $\begin{array}{l}\text { LTLB } \\
\text { STLB }\end{array}$ \\
\hline $\begin{array}{l}\text { UTII for certain } \\
\text { activities }\end{array}$ & $\begin{array}{l}-0.610 \\
-0.549\end{array}$ & $\begin{array}{c}0.518 \\
-0.729\end{array}$ & $\begin{array}{l}0.453 \\
0.799\end{array}$ \\
\hline $\begin{array}{l}\text { Number of } \\
\text { individual } \\
\text { entrepreneurs }\end{array}$ & $\begin{array}{l}0.942 \\
0.545\end{array}$ & $\begin{array}{l}-0.346 \\
0.501\end{array}$ & $\begin{array}{l}-0.224 \\
-0.517\end{array}$ \\
\hline $\begin{array}{l}\text { Number of small } \\
\text { enterprises }\end{array}$ & $\begin{array}{l}-0.810 \\
-0.597\end{array}$ & $\begin{array}{c}0.491 \\
-0.636\end{array}$ & $\begin{array}{l}0.417 \\
0.738\end{array}$ \\
\hline Personal income tax & $\begin{array}{l}-0.510 \\
-0.402\end{array}$ & $\begin{array}{c}0.370 \\
-0.577\end{array}$ & $\begin{array}{l}0.676 \\
0.581\end{array}$ \\
\hline $\begin{array}{l}\text { Taxes on } \\
\text { comprehensive } \\
\text { income }\end{array}$ & $\begin{array}{l}-0.621 \\
-0.558\end{array}$ & $\begin{array}{r}0.526 \\
-0.732\end{array}$ & $\begin{array}{l}0.446 \\
0.804\end{array}$ \\
\hline $\begin{array}{l}\text { Average monthly } \\
\text { nominal income per } \\
\text { capita }\end{array}$ & $\begin{array}{l}-0.711 \\
-0.776\end{array}$ & $\begin{array}{r}0.701 \\
-0.659\end{array}$ & $\begin{array}{l}0.226 \\
0.752\end{array}$ \\
\hline Population & $\begin{array}{l}0.357 \\
0.288\end{array}$ & $\begin{array}{r}-0.335 \\
0.807\end{array}$ & $\begin{array}{l}-0.410 \\
-0.862\end{array}$ \\
\hline $\begin{array}{l}\text { Number of large and } \\
\text { medium-sized } \\
\text { enterprises }\end{array}$ & $\begin{array}{l}0.531 \\
0.573\end{array}$ & $\begin{array}{c}-0.604 \\
0.720\end{array}$ & $\begin{array}{l}-0.218 \\
-0.852\end{array}$ \\
\hline
\end{tabular}

Table. 5 provides options for explaining the existence of a significant correlation between the city economic parameters and aggregated microparameters. The city parameter "The ratio of the population cash income value per capita to the value of the subsistence minimum" is excluded from the table because it does not have any meaningful connection. In addition, the city parameters "Average annual subsistence minimum per month", "Average monthly wages without social payments", "Average monthly nominal income per capita" and "Consumer spending per capita per month" showed virtually identical correlation with the micro-parameters "Revenues", "NCAB", "CAB" (except for the parameter "Average monthly salary without social payments," for which a significant correlation with $\mathrm{CRB}$ was revealed instead of CAB) and" STLB. For this reason, the conclusions on these parameters are combined in Table 5.

TABLE V. EXPLANATION FOR THE SIGNIFICANT CORRELATION BETWEEN THE CITY ECONOMIC PARAMETERS AND AGGREGATED MICRO-PARAMETERS

\begin{tabular}{|l|l|l|}
\hline City parameters & $\begin{array}{c}\text { Micro-exponent / } \\
\text { value of correlation } \\
\text { coefficient }\end{array}$ & $\begin{array}{l}\text { Explanations for } \\
\text { correlation }\end{array}$ \\
\hline $\begin{array}{l}\text { UTII for certain } \\
\text { activities }\end{array}$ & $\begin{array}{l}\text { CRB } \\
-0.729\end{array}$ & $\begin{array}{l}\text { The more the UTII is } \\
\text { taken from small } \\
\text { businesses, the less } \\
\text { money is left to form } \\
\text { capital and reserves }\end{array}$ \\
\cline { 2 - 3 } & STLB & $\begin{array}{l}\text { The more active the } \\
\text { small business uses } \\
\text { short-term liabilities, } \\
\text { the more active it is } \\
\text { and pays more taxes }\end{array}$ \\
\hline
\end{tabular}


Continuation Table V. Explanation for the significant correlation between the city economic parameters and aggregated microparameters

\begin{tabular}{|c|c|c|}
\hline $\begin{array}{l}\text { Number of } \\
\text { individual } \\
\text { entrepreneurs }\end{array}$ & $\begin{array}{l}\text { Revenues } \\
0.942\end{array}$ & $\begin{array}{l}\text { The fewer the small } \\
\text { entrepreneurs in the } \\
\text { city, the greater the } \\
\text { average revenue from } \\
\text { small businesses }\end{array}$ \\
\hline \multirow[t]{2}{*}{$\begin{array}{l}\text { Number of small } \\
\text { enterprises }\end{array}$} & $\begin{array}{l}\text { Revenues } \\
0.810\end{array}$ & $\begin{array}{l}\text { The more the small } \\
\text { enterprises, the higher } \\
\text { the average revenue. } \\
\text { It is likely that a good } \\
\text { business environment } \\
\text { affects the growth of } \\
\text { the number of small } \\
\text { enterprises and the } \\
\text { increase in their } \\
\text { average revenues }\end{array}$ \\
\hline & $\begin{array}{l}\text { STLB } \\
0.738\end{array}$ & $\begin{array}{l}\text { The more the small } \\
\text { enterprises, the more } \\
\text { actively they use } \\
\text { short-term liabilities } \\
\text { for their activities }\end{array}$ \\
\hline Personal income tax & $\begin{array}{l}\text { LTLB } \\
0.676\end{array}$ & $\begin{array}{l}\text { The more actively the } \\
\text { small business uses } \\
\text { long-term liabilities in } \\
\text { its activities, the more } \\
\text { funds it directs to pay } \\
\text { for labor and the more } \\
\text { it pays personal } \\
\text { income taxes }\end{array}$ \\
\hline \multirow[t]{2}{*}{$\begin{array}{l}\text { Taxes on } \\
\text { comprehensive } \\
\text { income }\end{array}$} & $\begin{array}{l}\text { CRB } \\
-0.732\end{array}$ & $\begin{array}{l}\text { With an increase in } \\
\text { the share of capital } \\
\text { and reserves, small } \\
\text { business enterprises } \\
\text { reduce the payment of } \\
\text { taxes on total income, } \\
\text { i.e. the taxable base } \\
\text { decreases }\end{array}$ \\
\hline & $\begin{array}{l}\text { STLB } \\
0.804\end{array}$ & $\begin{array}{l}\text { With the growth of } \\
\text { short-term liabilities, } \\
\text { the payment of taxes } \\
\text { on aggregate income } \\
\text { increases. Probably, } \\
\text { more active use of } \\
\text { short-term liabilities } \\
\text { increases the taxable } \\
\text { base }\end{array}$ \\
\hline \multirow{3}{*}{$\begin{array}{l}\text { Average annual } \\
\text { subsistence } \\
\text { minimum per } \\
\text { month }^{1)} \\
\text { Average monthly } \\
\text { wage excluding } \\
\text { social payments } \\
\text { Average monthly } \\
\text { nominal income per } \\
\text { capita }^{3)} \\
\text { The level of } \\
\text { consumer spending } \\
\text { per capita per } \\
\text { month }\end{array}$} & $\begin{array}{l}\text { Revenues } \\
\text { 1) }-0.781 \\
\text { 2) }-0.689 \\
\text { 3) }-0.711 \\
\text { 4) }-0.705\end{array}$ & $\begin{array}{l}\text { In the case of an } \\
\text { increase in the urban } \\
\text { parameter, small } \\
\text { businesses receive } \\
\text { less revenue, because } \\
\text { most of the } \\
\text { population income } \\
\text { goes to basic needs }\end{array}$ \\
\hline & $\begin{array}{l}\text { NCAB } \\
\text { 1) }-0.797 \\
\text { 2) }-0.679 \\
\text { 3) }-0.776 \\
\text { 4) }-0.736\end{array}$ & $\begin{array}{l}\text { With the growth of } \\
\text { the city parameter, } \\
\text { small business } \\
\text { enterprises have less } \\
\text { opportunities to invest } \\
\text { in long-term assets, } \\
\text { thus most money is } \\
\text { spent on their current } \\
\text { activities }\end{array}$ \\
\hline & $\begin{array}{l}\text { CAB } \\
\text { 1) } 0.760 \\
\text { 2) }-\end{array}$ & $\begin{array}{l}\text { With the growth of } \\
\text { the city parameter, the } \\
\text { small business } \\
\text { actively invests in } \\
\text { current assets to } \\
\text { maintain its current }\end{array}$ \\
\hline
\end{tabular}

3) 0.701

4) 0.685

\begin{tabular}{|c|c|c|}
\hline & & activity \\
\hline & $\begin{array}{l}\text { CRB } \\
\text { 1) - } \\
\text { 2) }-0.681 \\
\text { 3) - } \\
\text { 4) - }\end{array}$ & $\begin{array}{l}\text { With the growth of } \\
\text { average wages, small } \\
\text { enterprises reduce } \\
\text { their capital and } \\
\text { reserves. It is possible } \\
\text { that those funds that } \\
\text { could go to the } \\
\text { formation of capital } \\
\text { go to wages and } \\
\text { related taxes and } \\
\text { contributions }\end{array}$ \\
\hline & $\begin{array}{l}\text { STLB } \\
\text { 1) } 0.776 \\
\text { 2) } 0.767 \\
\text { 3) } 0.752 \\
\text { 4) } 0.752\end{array}$ & $\begin{array}{l}\text { With the growth of } \\
\text { the urban parameter, } \\
\text { small businesses are } \\
\text { more active in using } \\
\text { short-term liabilities } \\
\text { to maintain their } \\
\text { current activity }\end{array}$ \\
\hline & $\begin{array}{l}\text { CRB } \\
0.807\end{array}$ & $\begin{array}{l}\text { As the population } \\
\text { grows, the capital and } \\
\text { reserves of the small } \\
\text { businesses grow }\end{array}$ \\
\hline & $\begin{array}{l}\text { STLB } \\
-0.862\end{array}$ & $\begin{array}{l}\text { As the population } \\
\text { grows, short-term } \\
\text { liabilities are reduced. } \\
\text { It is probably affected } \\
\text { by the increased } \\
\text { competition between } \\
\text { the population and the } \\
\text { small enterprises for } \\
\text { "short" money }\end{array}$ \\
\hline \multirow[t]{2}{*}{ Population } & $\begin{array}{l}\text { CRB } \\
0.720\end{array}$ & $\begin{array}{l}\text { With the increase in } \\
\text { the number of large } \\
\text { and medium } \\
\text { businesses, capital } \\
\text { and reserves rise in } \\
\text { small business. This is } \\
\text { probably affected by } \\
\text { increased competition } \\
\text { between the small } \\
\text { business and the large } \\
\text { and medium } \\
\text { businesses }\end{array}$ \\
\hline & $\begin{array}{l}\text { STLB } \\
-0.852\end{array}$ & $\begin{array}{l}\text { With the growth in } \\
\text { the number of } \\
\text { enterprises in the } \\
\text { large and medium } \\
\text { businesses, a decrease } \\
\text { in the share of short- } \\
\text { term liabilities is } \\
\text { observed. It may be } \\
\text { due to the increased } \\
\text { competition between } \\
\text { large and medium } \\
\text { businesses and small } \\
\text { enterprises for "short" } \\
\text { money }\end{array}$ \\
\hline
\end{tabular}

\section{CONCLUSION}

Based on the results of the studies, the following outcome was obtained.

1. The list of economic and social parameters characterizing a single city was analyzed. The ways of selection of the most significant urban parameters for studying their interrelation with small business were substantiated.

2. The choice and composition of aggregated 
micro-parameters of small businesses for the study was justified. The transformation of the micro-parameters under study into a format optimal for research was described.

3. The existence of significant correlation links between the city economic parameters and the aggregated micro-parameters of small business on their territory was proved. The significance evaluation was carried out based on the Student's t-criterion.

4. The economic justification for the existence of a correlation between the economic and social parameters of the city and micro-parameters was given.

The results obtained and the conclusions drawn from them are intended, on the one hand, to help small businesses find their place in the economy of the "native" city and determine the most optimal strategy for their development. On the other hand, research materials can be used by municipalities as a basis for development projects and programs for small business in their jurisdictions.

\section{ACKNOWLEDGMENT}

The research is carried out at Tomsk Polytechnic University within the framework of Tomsk Polytechnic University Competitiveness Enhancement Program grant.

\section{REFERENCES}

[1] A.N. Vazhdaev, "Information system for the study of small enterprises for the simultaneous implementation of several types of economic activity," Bulletin of Southern Federal University. Engineering Sciences, 2014, vol. 4, pp. 197-204.

[2] "Small enterprise", Economic dictionary. Access mode: http://abc.informbureau.com/html/ iaeia idaaidessoea.html (accessed date: 02.08.2012).

[3] A.Yu. Manokhin, "Strategy of development of small and medium business in modern Russia. Monograph," Russian Higher Education University (Tambov branch). Access mode: http://www.tambov-rosnou.ru/monograf/ (accessed date: 01.07.2012).

[4] A.N. Vazhdaev, "Application of the principle of open management in small enterprises with several activities," Bulletin of SFU. Engineering Sciences, 2013, vol. 5, pp. $225-$ 230.

[5] A.N. Vazhdaev, "Model and algorithm for analyzing the process of self-organization of new investment projects on the basis of previous ones," Bulletin of SFU. Engineering Sciences, 2009, vol. 2, pp. 46-49.

[6] Th.J. Peters, R.H. Waterman Jr., "In Search of Excellence: Lessons from the Most Successful Companies in America", Translation from English, Moscow, Publishing house "Williams", 2005.

[7] "Comprehensive program of socio-economic development of the Yurga urban district of the Kemerovo region" [digital resource] / Official site of the administration of the city of Yurga. Access mode:

http://www.adm.yrg.kuzbass.net/pagedata/00000181/files/kpsr1_ 2025.pdf (accessed date: 01.10.2012).

[8] "Software product 'Directory OKVED' " [digital resource]. Access mode: http://www.tradesoft.ru.

[9] "Report of the head of the administration of the Yurga urban district on the achieved values of parameters for assessing the effectiveness of local self-government bodies of urban districts and municipal districts in 2012 and their planned values for a 3year period" [digital resource] / site of the administration of Yurga. Access mode: http://www.adm.yrg.kuzbass.net/ pagedata/00000536/doklad.pdf (accessed date: 01.03.2014).

[10] "Database of the Kemerovo region municipality unit passport 'Parameters characterizing the state of economics and social sphere of city' Urban districts of the Kemerovo region," City district, urban district with the intra-urban division "Yurginsky" for 2006, 2007, 2008, 2009, 2010, 2011, 2012, 2013 , 2014, 2015 [digital resource]. Access mode: http://www.gks.ru/scripts/db_inet2/passport/table.aspx?opt=327 490002006200720082009201020112012201320142015 (accessed date: November 20, 2016).

[11] A.A. Belov, B.A. Ballod, N.N. Elizarova, "Theory of Probability and Mathematical Statistics", Rostov on Don, Phoenix, 2008, pp. 318. 